\title{
A vastag- és végbéldaganat okozta országos epidemiológiai és egészségbiztosítási betegségteher Magyarországon
}

\author{
Kívés Zsuzsanna ${ }^{1,2}$. Endrei Dóra dr. ${ }^{1,2}$. Elmer Diána ${ }^{1,2}$ \\ Csákvári Tímea ${ }^{2,3}$ - Kajos Luca Fanni ${ }^{1}$ - Boncz Imre dr. ${ }^{1,2}$ \\ Mangel László dr. ${ }^{4}$. Mihály-Vajda Réka dr. ${ }^{1,2}$
}

${ }^{1}$ Pécsi Tudományegyetem, Egészségtudományi Kar, Egészségbiztosítási Intézet, Pécs

${ }^{2}$ Pécsi Tudományegyetem, Egészségtudományi Kar,

Real World \& Big Data Egészség-gazdaságtani Kutatóközpont, Pécs

${ }^{3}$ Pécsi Tudományegyetem, Egészségtudományi Kar, Egészségbiztosítási Intézet, Zalaegerszeg

${ }^{4}$ Pécsi Tudományegyetem, Általános Orvostudományi Kar, Klinikai Központ, Onkoterápiás Intézet, Pécs

Bevezetés: Magyarországon a vastag- és a végbéldaganat mindkét nem esetében a harmadik leggyakoribb daganatos megbetegedés és a második leggyakoribb halálok.

Célkitüzés: Elemzésünk célja volt a vastag- és végbéldaganat okozta éves epidemiológiai és egészségbiztosítási betegségteher meghatározása Magyarországon.

Adatok és módszerek: Az adatok a Nemzeti Egészségbiztosítási Alapkezelő (NEAK) finanszírozási adatbázisából származnak, és a 2018. évet fedik le. A daganat típusait a Betegségek Nemzetközi Osztályozása (BNO, 10. revízió) szerinti C18-as, C19-es, C20-as, C21-es, D010-D014-es és D12-es kóddal azonosítottuk. Meghatároztuk az éves betegszámokat korcsoportos és nemek szerinti bontásban, a prevalenciát 100000 lakosra, az éves egészségbiztosítási kiadásokat valamennyi ellátási formára és daganattípusra vonatkozóan.

Eredmények: A vastag- és végbéldaganatok kezelésére a NEAK 21,7 milliárd Ft-ot (80,2 millió USD; 68,0 millió EUR) költött 2018-ban. A költségek 58,0\%-át az aktívfekvőbeteg-szakellátás költségei teszik ki. Az összköltségek megoszlása szerint a legmagasabb költségek a férfiaknál (4,98 milliárd Ft) és a nóknél $(3,25$ milliárd Ft) is a $65-74$ éves korcsoportban figyelhetők meg. A legnagyobb betegszámot a járóbeteg-szakellátás esetében találtuk: 88134 fó, ezt a háziorvosi ellátás (55 324 fó) és a CT, MRI (28 426 fó) követte. A vastagbél rosszindulatú daganata esetében az egy betegre jutó aktívfekvőbeteg-kassza alapján az éves egészségbiztosítási kiadás 1,206 millió Ft (4463 USD/3782 EUR) volt a férfiak és 1,260 millió Ft (4661 USD/3950 EUR) a nők esetében.

Következtetés: Hazánkban az aktívfekvőbeteg-szakellátás bizonyult a fő költségtényezőnek, mely magában foglalja az onkoterápiás gyógyszeres költségeket is.

Orv Hetil. 2021; 162(Suppl 1): 14-21.

Kulcsszavak: vastagbéldaganat, betegségteher, egészségpolitika, egészségbiztosítás, finanszírozás

\section{Epidemiological disease burden and annual health insurance treatment cost of colorectal cancer in Hungary}

Introduction: Colorectal cancer is the third most common type of cancer and the second most common cause of mortality in Hungary in both sexes.

Objective: The aim of our study was to determine the annual epidemiological disease burden and health insurance cost of colorectal cancer in Hungary.

Data and methods: Data were derived from the financial database of the National Health Insurance Fund Administration (NHIFA) of Hungary for the year 2018. Types of cancer were identified with the following codes of the International Classification of Diseases, 10th revision: C18, C19, C20, C21, D010-D014, D12. The data analysed included annual patient numbers according to age groups and sex, prevalence of care utilisation per 100000 population, and annual health insurance costs for all types of care and all cancer types.

Results: In 2018, NHIFA spent 21.7 billion HUF (80.2 million USD, 68.0 million EUR) on the treatment of colorectal cancer. $58.0 \%$ of the costs was spent on acute inpatient care. Regarding total costs, the highest costs were found 
in the 65-74 age group in both men (4.98 billion HUF) and women (3.25 billion HUF). The highest patient numbers were in outpatient care: 88134 patients, general practice care ( 55324 patients) and CT, MRI (28 426 patients). The annual health care treatment cost per patient was 1.206 million HUF (4463 USD/3782 EUR) in men and 1.260 million HUF (4661 USD/3950 EUR) in women.

Conclusion: Acute inpatient care, including the costs of oncotherapeutic pharmaceuticals, was found to be the major cost driver in Hungary.

Keywords: colon cancer, disease burden, health policy, health insurance, financing

Kívés Zs, Endrei D, Elmer D, Csákvári T, Kajos LF, Boncz I, Mangel L, Mihály-Vajda R. [Epidemiological disease burden and annual health insurance treatment cost of colorectal cancer in Hungary]. Orv Hetil. 2021; 162(Suppl 1): $14-21$.

(Beérkezett: 2021. január 2.; elfogadva: 2021. január 18.)

\begin{abstract}
Rövidítések
BNO = Betegségek Nemzetközi Osztályozása; $\mathrm{CT}=($ computed tomography) komputertomográfia; EFOP = Emberi Erőforrás Fejlesztési Operatív Program; GDP $=$ (gross domestic product) bruttó hazai termék; gFOBT = (guaiac fecal occult blood test) guajakalapú székletokkultvér-vizsgálat; iFOBT = (immunochemical fecal occult blood test) immunkémiai székletokkultvér-vizsgálat; MRI = (magnetic resonance imaging) mágnesesrezonancia-képalkotás; NEAK = Nemzeti Egészségbiztosítási Alapkezelő; PET = pozitronemissziós tomográfia; $\mathrm{PPP}=($ purchasing power parity) vásárlóerő-paritás; VEKOP = Versenyképes Közép-Magyarország Operatív Program
\end{abstract}

A vastag- és végbéldaganat a fejlett országokban jelentős népegészségügyi problémát jelent. A vastagbéldaganat az éves incidencia alapján Európában a férfiak körében a harmadik (23,6 eset/100 000 fó), a nóknél a második (16,3 eset/100 000 fó) leggyakoribb daganatos megbetegedés [1]. Magyarország Európán belül mindkét nem esetén az első helyen áll a halálozási mutatók alapján, míg az országos adatok szerint mindkét nem esetében ez a harmadik leggyakoribb daganatos megbetegedés és a második leggyakoribb halálok. 2017-ben a Nemzeti Rákregiszter adatai szerint 5917 férfit és 4732 nót diagnosztizáltak a vastagbél, a szigmabél-végbél határ, a végbél, a végbélnyílás és az anuscsatorna rosszindulatú daganatával (C18-C21) [2,3]. A nemzetközi összevetésben ki kell emelni, hogy a kelet-európai országokban magas volt az elórehaladott stádiumú esetek aránya (>30\%), mely korrelált a rosszabb 5 éves túlélési mutatókkal [4]. Az életkor szerint standardizált 5 éves nettó túlélés az Amerikai Egyesült Államokban 58\%, hasonló, mint Észak- és Nyugat-Európában (54-56\%), a fejlett világban a legalacsonyabb pedig Kelet-Európában (42\%) [5]. Magyarországon az 5 éves túlélés 30-41\% [6,7].

Az elmúlt két évtizedben az egészségügyi ellátásra fordított költségek - bár eltérő mértékben, de - folyamatosan emelkedtek a fejlett országokban [8]. Magyarországon az egészségügyi kiadások jóval az uniós átlag alatt vannak. 2015-ben Magyarország fejenként 1428 EUR-t költött az egészségügyre (a GDP 7,2\%-át), ami körül- belül a fele a 2797 EUR uniós átlagnak (a GDP 9,9\%-a) és a hatodik legalacsonyabb érték az Európai Unióban. Az egészségügyi kiadások kétharmada állami forrásokból, míg a többi része a közvetlen lakossági hozzájárulásból származik.

Magyarország az ötödik legmagasabb arányú elkerülhető halálozási arányszámról számol be az Európai Unión belül, mely az uniós átlag kétszeresének felel meg. A vastag- és végbéldaganat is az elkerülhető halálokok közé sorolható. A betegségből eredő halálozás csökkenthető a primer prevencióval - hiszen ezen betegség kialakulásának rizikójában az életmód kiemelt szereppel bír és rövid távon a szürôvizsgálatok révén is. Számos pilotprogram zajlott az elmúlt évtizedekben hazánkban, de a populációs alapú szúroóprogram mind ez idáig nem valósult meg [9-12].

A vastag- és végbéldaganatok kezeléséhez kapcsolódó gazdasági költségek általában sok tényezőtől függően változhatnak, itt említhetjük például a betegség stádiumát a diagnózis felállításakor, a beteg életkorát, az egyedi elemzésben szereplő megfigyelési időt és az orvosi szolgáltatások típusait $[13,14]$. Korábban a szervezett mammográfiás emlőszưrés és a méhnyakszűrés elindítását megelőzően átfogó elemzések készülttek a kórképekhez kapcsolódó egészségbiztosítási kiadásokról. Ugyanezen korábbi és többi más elemzésben bemutatásra kerültek a vastag- és végbéldaganatokhoz kapcsolódó, elmúlt évtizedbeli egészségbiztosítási kiadások is [1518].

A 2000-es évek óta az ajánlások szerint a legköltséghatékonyabb eljárás a rendelkezésre álló szưrőmódszerek alkalmazásával a korai felismerést szolgáló, populációs alapú szűrések megvalósítása [19]. Ran és mtsai szisztematikus áttekintése alapján az évente vagy kétévente végzett gFOBT vagy iFOBT, a 10 évente végzett kolonoszkópia, az 5 évente végzett flexibilis szigmoidoszkópia költséghatékonynak bizonyul a szúrés elmaradásával szemben. Az Egyesült Államokban ugyanakkor a 10 évente végzett kolonoszkópia minden más szûrőmódszernél hatékonyabbnak bizonyult [20]. Az utóbbi haté- 
konyságában a szürésen való részvétel magas aránya (70$80 \%$ ) is szerepet játszik [21].

Hazánkban a szûrés a Népegészségügyi Központ keretein belül az EFOP-1.8.1-VEKOP-15-2016-00001. azonosítószámú, „Komplex népegészségügyi szűrések” címú kiemelt projekt révén valósul meg. A kormány döntése értelmében a projekt 2023. június 30-ig tovább folytatódik. A projekt célja a lakosság egészségtudatosságának fejlesztése - beleértve a szürővizsgálatokon való részvételi hajlandóságot, továbbá a szưrôvizsgálati rendszer felülvizsgálatát és annak korszerüsítését, biztosítva a szưrővizsgálatok teljes körû szabályozottságát -, valamint a szervezett lakossági kétlépcsős vastagbélszűrés országos kiterjesztése a teljes 50-70 éves korosztályba tartozó célpopulációra [22].

Jelen elemzésünk célja a vastag- és végbéldaganatok epidemiológiai mutatóinak és a kivizsgálási, terápiás és gondozási költségeiket is magukban foglaló, 2018. évi egészségbiztosítási kiadásaiknak a feltérképezése volt.

\section{Adatok és módszerek}

Az elemzésben felhasznált adatok a Nemzeti Egészségbiztosítási Alapkezelő (NEAK) finanszírozási adatbázisából származnak, és a 2018. évet fedik le. Az elemzésbe bevont daganattípusok a Betegségek Nemzetközi Osztályozása (BNO, 10. revízió) szerinti bontásban a következők voltak: vastagbél rosszindulatú daganata (C18); a szigmabél-végbél határ rosszindulatú daganata (C19); a végbél rosszindulatú daganata (C20); a végbélnyílás és az anuscsatorna rosszindulatú daganata (C21); a vastagbél, a végbél, a végbélnyílás és az anuscsatorna in situ daganata (D010, D011, D012, D013, D014); a vastagbél, a végbél, a végbélnyílás és az anuscsatorna jóindulatú daganata (D12).

A vastag- és végbéldaganatok számolt kezelési költségei tartalmazzák a háziorvosi ellátás, az otthoni szakápolás, a betegszállítás, a járóbeteg-szakellátás, a gondozóintézeti gondozás, a laboratóriumi vizsgálatok, a CT/ MRI, a PET, az aktív- és krónikusfekvőbeteg-szakellátás költségeit, továbbá a tételes elszámolás alá eső kiadásokat (egyszer használatos eszközök, implantátumok, gyógyszerek és nagy értékű mútéti eljárások), a gyógyszerek árához nyújtott társadalombiztosítási támogatást és a gyógyászati segédeszközök ártámogatását. Az aktív- és krónikusfekvőbeteg-szakellátás adatai közül a „3. ápolást kódoló fódiagnózis" tétel adatait elemeztük. A daganatos betegek ellátása során felhasznált gyógyszereket a NEAK nem minden esetben a gyógyszerkasszából, hanem az aktívfekvőbeteg-szakellátás kasszájából finanszírozza. A mentőszolgálat által végzett mentés esetében költség nem, csak kilométeradatok álltak rendelkezésünkre.

A NEAK az adatvédelmi szabályainak megfelelően egyedi adatokból aggregált adatokat szolgáltatott számunkra. A NEAK-adatkérést a vonatkozó NEAK-

1. táblázat |A vastag- és végbéldaganatok betegszámai (fö) ellátási formánként (NEAK, 2018)

\begin{tabular}{|c|c|c|c|c|c|c|c|}
\hline Ellátási forma & $\begin{array}{c}\text { C18 } \\
\text { A vastagbél } \\
\text { rosszindulatú } \\
\text { daganata }\end{array}$ & $\begin{array}{l}\text { C19 } \\
\text { A szigmabél- } \\
\text { végbél határ } \\
\text { rosszindulatú } \\
\text { daganata }\end{array}$ & $\begin{array}{c}\text { C20 } \\
\text { A végbél } \\
\text { rosszindulatú } \\
\text { daganata }\end{array}$ & $\begin{array}{c}\text { C21 } \\
\text { A végbélnyílás } \\
\text { és az } \\
\text { anuscsatorna } \\
\text { rosszindulatú } \\
\text { daganata }\end{array}$ & $\begin{array}{l}\text { D010-D014 } \\
\text { A vastagbél, } \\
\text { a végbél, } \\
\text { a végbélnyílás } \\
\text { és az } \\
\text { anuscsatorna } \\
\text { in situ } \\
\text { daganata }\end{array}$ & $\begin{array}{c}\text { Dl2 } \\
\text { A vastagbél, } \\
\text { a végbél, } \\
\text { a végbélnyílás } \\
\text { és az } \\
\text { anuscsatorna } \\
\text { jóindulatú } \\
\text { daganata }\end{array}$ & $\begin{array}{l}\text { Betegszám } \\
\text { összesen (fö) }\end{array}$ \\
\hline Háziorvosi ellátás & 23771 & 3783 & 12567 & 969 & 304 & 13930 & 55324 \\
\hline Otthoni szakápolás & 241 & 33 & 195 & 5 & 0 & 4 & 478 \\
\hline Betegszállítás & 1619 & 259 & 1179 & 69 & 21 & 230 & 3377 \\
\hline Mentés & 675 & 20 & 433 & 18 & 5 & 7 & 1158 \\
\hline Járóbeteg-szakellátás & 28673 & 5154 & 18363 & 1078 & 495 & 34371 & 88134 \\
\hline Gondozóintézeti gondozás & 8469 & 1240 & 4676 & 112 & 79 & 327 & 14903 \\
\hline Laboratóriumi ellátás & 10022 & 1531 & 6013 & 233 & 80 & 3661 & 21540 \\
\hline $\mathrm{CT}, \mathrm{MRI}$ & 15546 & 2130 & 9125 & 573 & 100 & 952 & 28426 \\
\hline PET & 1577 & 258 & 1048 & 32 & 0 & 0 & 2915 \\
\hline Aktívfekvőbeteg-szakellátás & 7672 & 1455 & 4997 & 280 & 27 & 6929 & 21360 \\
\hline Krónikusfekvőbeteg-szakellátás & 626 & 78 & 367 & 25 & 0 & 21 & 1117 \\
\hline Tételes elszámolás & 0 & 0 & 0 & 0 & 0 & 0 & 0 \\
\hline Gyógyszer-ártámogatás & 11207 & 1777 & 7044 & 469 & 85 & 2477 & 23059 \\
\hline $\begin{array}{l}\text { Gyógyászati segédeszközök } \\
\text { ártámogatása }\end{array}$ & 1891 & 553 & 5535 & 178 & 10 & 65 & 8232 \\
\hline
\end{tabular}

CT = komputertomográfia; MRI = mágnesesrezonancia-képalkotás; NEAK = Nemzeti Egészségbiztosítási Alapkezelő; PET = pozitronemissziós tomográfia 
szabályzat szerint készítettük el, részletes leválogatási algoritmust megadva, amely alapján a NEAK munkatársai válogatták le az adatokat az egészségbiztosítási adatbázisból. Etikai jóváhagyás a jelen kutatáshoz nem volt szükséges.

$\mathrm{Az}$ epidemiológiai betegségteher vizsgálata során meghatároztuk az éves betegszámot nemenkénti bontásban, a 100000 lakosra jutó igénybevételi prevalenciát pedig korcsoportos és nemek szerinti bontásban. A prevalencia kiszámításánál a Központi Statisztikai Hivatal 2018. évi, a magyarországi lakónépességre vonatkozó adatbázisát vettük alapul (4 671602 fó férfi, 5106769 fó nő). Az egészségbiztosítási betegségteher vizsgálata során pedig meghatároztuk az egészségbiztosítási kiadásokat és a költségek megoszlását korcsoportos és nemek szerinti bontásban is. A teljes egészségbiztosítási kiadást és az egy före eső egészségbiztosítási kiadást USD-ban (270,25 Ft/1 USD) és EUR-ban (318,87 Ft/1 EUR) is a Magyar Nemzeti Bank szerinti 2018. évi éves átlagárfolyamon adtuk meg.

A magyar egészségügyi rendszer felépítésének, múködésének és finanszírozásának részletes leírása máshol megtalálható [23-29].

\section{Eredmények}

A vastag- és végbéldaganatok egyes típusaihoz tartozó betegszámokat az 1. táblázatban foglaltuk össze ellátási formánként. A legmagasabb betegszámot a vastagbél, a végbél, a végbélnyílás és az anuscsatorna jóindulatú daganatánál (D12: 34371 beteg), a vastagbél rosszindulatú daganatánál (C18: 28673 beteg) és a végbél rosszindulatú daganatánál (C20: 18363 beteg) láthatjuk a járóbeteg-szakellátás esetében. A második legmagasabb betegszám a háziorvosi ellátásnál található az egyes daganattípusoknál.

A legköltségesebb ellátási forma a fekvőbeteg-szakellátás, ahol a betegek aránya a legmagasabb a vastagbél rosszindulatú daganata (C18: 35,9\%), a végbél jóindula-

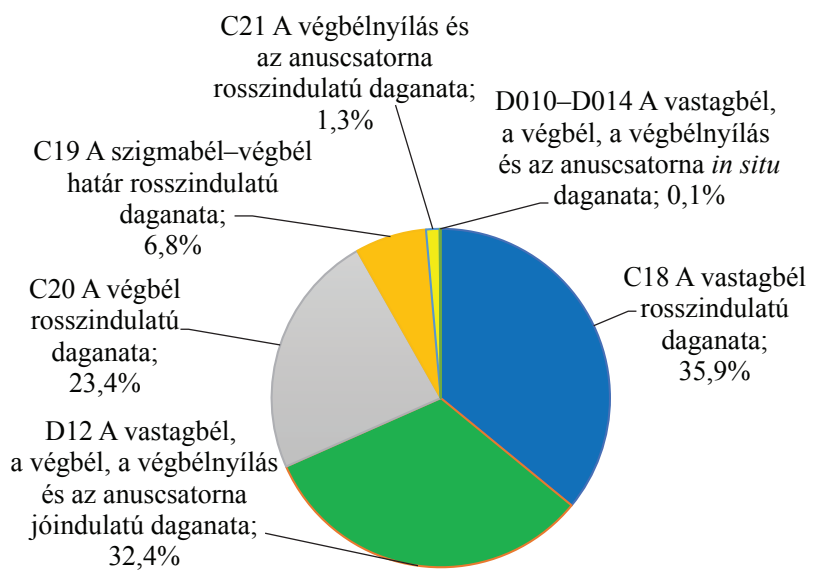

1. ábra $\quad$ A NEAK-közfinanszírozás keretében történt aktívfekvőbetegellátásban részesített betegek megoszlása a vastag- és végbéldaganatok típusai alapján (NEAK, 2018)

NEAK = Nemzeti Egészségbiztosítási Alapkezelő

tú daganata (D12: 32,4\%), valamint a végbél rosszindulatú daganata (C20: 23,4\%) esetében (1. ábra).

A 2. ábrán az aktívfekvőbeteg-szakellátás során ellátott betegek 100000 nőre és férfira számított prevalenciáját adtuk meg betegségtípusonként. A legmagasabb prevalenciát a fekvőbeteg-ellátásban a vastagbél rosszindulatú daganata esetében láthatjuk 2018-ban, amelynél a férfiak prevalenciája 88,7 fö, a nőké 69,0 fö volt 100000 före vetítve.

A férfiak aránya a legtöbb betegségtípus, ellátási forma esetén jellemzően magasabb, mint a nőké. Az ellátási formákon belül a férfiak aránya a C18-nál 47,7-57,3\%, a C19-nél 42,4-60,1\%, a C20-nál 58,1-63,8\%, a C21nél 35,7-60,0\%, a D010-nél 37,0-80,0\%, a Dl2-nél 38,2-75,0\% között mozgott.

A NEAK a 2018. évben 21,7 milliárd Ft-ot költött a vastag- és végbéldaganatok kezelésére, mely 68,0 millió EUR-nak és 80,2 millió USD-nak felel meg. A daganattípusok közül a vastagbél rosszindulatú daganatának ke-

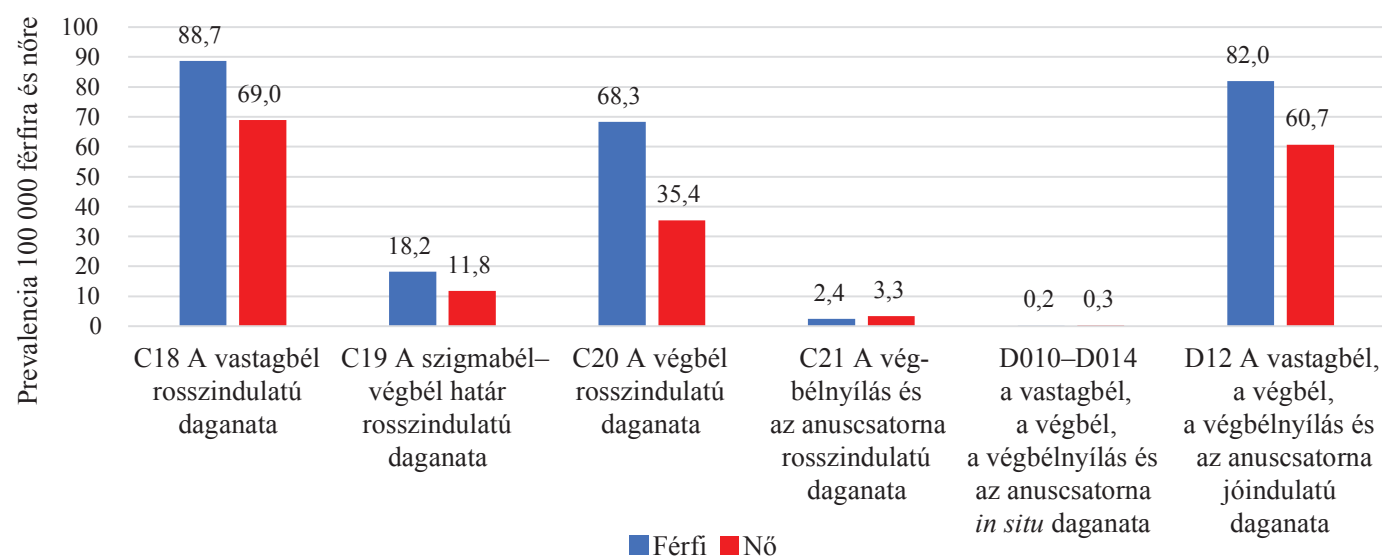

2. ábra $\quad$ A vastag- és végbéldaganatos betegek prevalenciája 100000 nőre és férfira vonatkozóan az aktívfekvőbeteg-szakellátás egészségbiztosítási igénybevételi adatai alapján (NEAK, 2018)

NEAK = Nemzeti Egészségbiztosítási Alapkezelő 


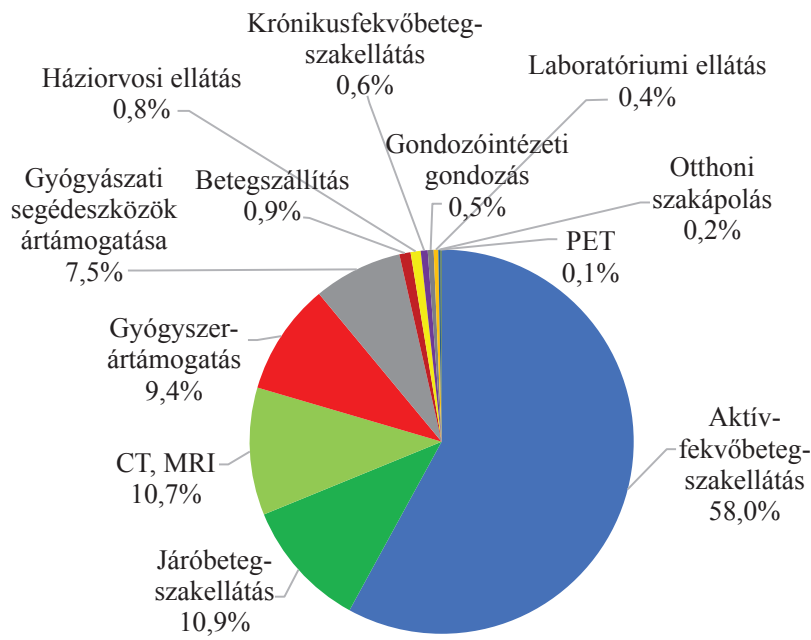

3. ábra

A NEAK-közfinanszírozás keretében ellátott vastag- és végbél daganatos betegek egészségbiztosítási kiadásainak megoszlása ellátási formánként (NEAK, 2018)

$\mathrm{CT}=$ komputertomográfia MRI = mágnesesrezonancia-képal kotás; NEAK = Nemzeti Egészségbiztosítási Alapkezelő; PET = pozitronemissziós tomográfia

zelésére fordították a legmagasabb összeget $(9,44$ milliárd $\mathrm{Ft}$ ), a második legmagasabb költség a végbél rosszindulatú daganata esetében figyelhető meg $(7,89$ milliárd Ft). Mindkét daganattípusnál az aktívfekvőbeteg-szakellátás költségei a legmagasabbak. A legalacsonyabb kiadás az in situ daganatoknál látható (2. táblázat). Minden daganattípust és ellátási formát figyelembe véve a költségek 58,0\%-át az aktívfekvőbeteg-szakellátás költségei teszik ki (3. ábra).

Az egészségbiztosítási kiadások tételei az egyes ellátási formák szerint változatos képet mutatnak. A legnagyobb kiadási tétel az aktívfekvőbeteg-szakellátásban jelenik meg, ez éves szinten 12,57 milliárd Ft. Ezt követi a járóbeteg-szakellátás (2,35 milliárd Ft), a CT/MRI költsége (2,33 milliárd $\mathrm{Ft})$ és a gyógyszer-ártámogatások tételei (2,05 milliárd Ft). Daganattípusonként is az aktívfekvőbeteg-szakellátás költségei a legmagasabbak (C18: 62,5\%; C19: 67,2\%; C20: 57,8\%; C21: 49,9\%; D010-D014:
43,7\%), kivéve a jóindulatú elváltozásokhoz kapcsolódó költségeket, amelyek esetében a járóbeteg-szakellátás költségei magasabbak (D12: 58,4\%). A második legmagasabb költséget a C18 (13,4\%), a C19 (11,0\%) és a C21 (16,1\%) esetében a CT/MRI kiadások teszik ki. A vastagbél rosszindulatú daganatánál $(\mathrm{Cl} 8)$ az egy betegre eső CT/MRI költség 88662 Ft (15 546 beteg). A C20 szerinti daganatnál a gyógyászati segédeszköz ártámogatása, a D010-D014 szerinti daganatoknál a járóbeteg-szakellátás, míg a D12-es kód szerinti daganattípusnál a fekvőbeteg-szakellátás a második legköltségesebb ellátási forma.

Az aktívfekvőbeteg-szakellátás esetében a végbél rosszindulatú daganatainak (C20) költsége magasabb az alacsonyabb betegszám (4997 fó) mellett is, mint a vastagbél rosszindulatú daganatainak (C18) költsége magasabb betegszám mellett (7672 fó). Az aktívfekvőbeteg-szakellátás egy betegre jutó éves költsége a vastagbél rosszindulatú daganatánál (C18) 1,2 millió Ft/beteg (4554 USD; 3859 EUR), a végbél rosszindulatú daganatánál (C20) 1,6 millió Ft/beteg (5842 USD; 4951 EUR).

A gyógyszer-ártámogatás (amely nem foglalja magában az onkoterápiás gyógyszeres kezelések jelentős részét) minden daganattípust és ellátási formát figyelembe véve az összköltség 9,4\%-át tette ki (6,4 millió EUR; 7,6 millió USD). A legmagasabb gyógyszerköltség a vastagbél rosszindulatú daganatánál (C18: 11207 beteg 106421 Ft/beteg; 334 EUR; 394 USD) és a végbél rosszindulatú daganatánál (C20: 7044 beteg - 99420 Ft/beteg; 312 EUR; 368 USD) figyelhető meg.

A valamennyi daganattípust magukban foglaló összköltségek nemek és korcsoportok szerinti megoszlása alapján a legmagasabb költségek a férfiaknál (4,99 milliárd $\mathrm{Ft}$ ) és a nóknél (3,26 milliárd $\mathrm{Ft})$ is a 65-74 éves korcsoportban figyelhetók meg (4. ábra). Ebben a korcsoportban minden daganattípus esetén magasabbak a férfiakhoz kapcsolódó költségek, kivéve a C21-es kód szerinti betegséget, amelynél az 55-64 éves, a 65-74 éves és a 75 év feletti korcsoportban, és a D010-es kód szerinti betegséget, amelynél a 65-74 éves és a 75 feletti korcsoportban is a nőkhöz kapcsolódik magasabb költség.

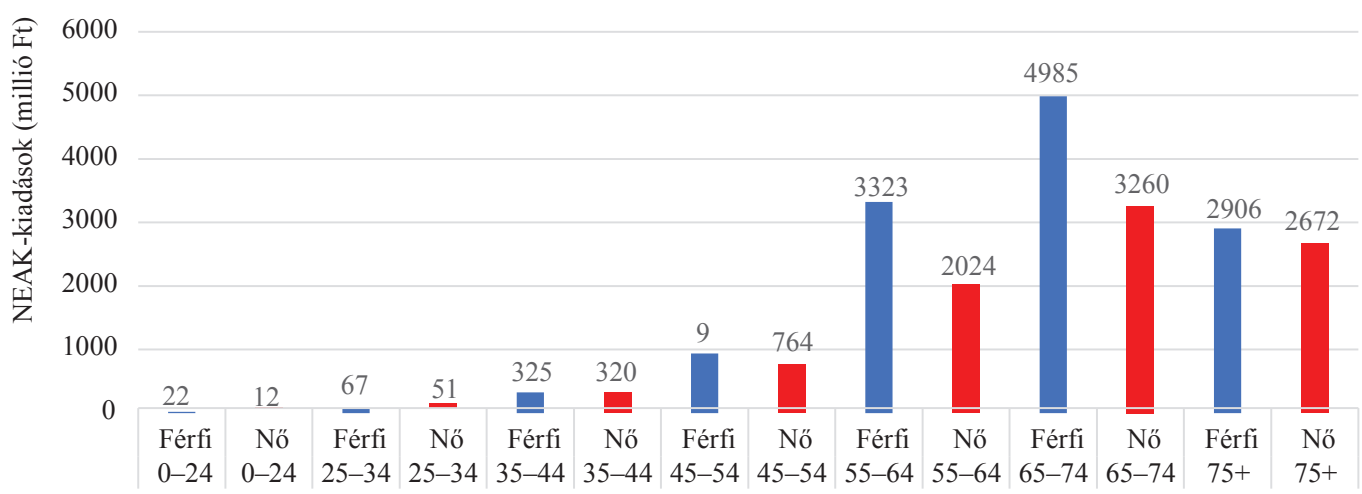

Korcsoportok (év)

\begin{tabular}{l|l} 
4. ábra & $\begin{array}{l}\text { A vastag- és végbéldaganatok összes egészségbiztosítási kiadásai korcsoportok és nemek szerint (millió Ft) (2018) } \\
\text { NEAK = Nemzeti Egészségbiztosítási Alapkezelő }\end{array}$
\end{tabular} 
2. táblázat |A vastag- és végbéldaganatok kezelésének egészségbiztosítási kiadásai ellátási formánként (NEAK, 2018)

\begin{tabular}{|c|c|c|c|c|c|c|c|}
\hline Ellátási forma & $\begin{array}{c}\text { C18 } \\
\text { A vastagbél } \\
\text { rosszindulatú } \\
\text { daganata } \\
(\mathrm{Ft})\end{array}$ & $\begin{array}{l}\text { C19 } \\
\text { A szigmabél- } \\
\text { végbél határ } \\
\text { rosszindulatú } \\
\text { daganata } \\
(\mathrm{Ft})\end{array}$ & $\begin{array}{c}\text { C20 } \\
\text { A végbél } \\
\text { rosszindulatú } \\
\text { daganata } \\
(\mathrm{Ft})\end{array}$ & $\begin{array}{c}\text { C21 } \\
\text { A végbélnyílás } \\
\text { és az } \\
\text { anuscsatorna } \\
\text { rosszindulatú } \\
\text { daganata } \\
(\mathrm{Ft})\end{array}$ & $\begin{array}{l}\text { D010-D014 } \\
\text { A vastagbél, } \\
\text { a végbél, } \\
\text { a végbél- } \\
\text { nyílás és az } \\
\text { anuscsatorna } \\
\text { in situ } \\
\text { daganata } \\
\text { (Ft) }\end{array}$ & $\begin{array}{c}\mathrm{D} 12 \\
\text { A vastagbél, } \\
\text { a végbél, } \\
\text { a végbélnyílás és } \\
\text { az anuscsatorna } \\
\text { jóindulatú } \\
\text { daganata } \\
(\mathrm{Ft})\end{array}$ & $\begin{array}{l}\text { Összesen } \\
(\mathrm{Ft})\end{array}$ \\
\hline Háziorvosi ellátás & 88237763 & 13383877 & 54025910 & 2917749 & 698963 & 24623656 & 183887918 \\
\hline Otthoni szakápolás & 17451087 & 2649459 & 17526123 & 441262 & 0 & 330780 & 38398711 \\
\hline Betegszállítás & 74879238 & 12866899 & 109914434 & 1883335 & 507237 & 5047155 & 205098298 \\
\hline Mentés & - & - & - & - & - & - & - \\
\hline Járóbeteg-szakellátás & 450214439 & 60210004 & 326953550 & 12598505 & 6044039 & 1498771596 & 2354792133 \\
\hline $\begin{array}{l}\text { Gondozóintézeti } \\
\text { gondozás }\end{array}$ & 62816378 & 7830261 & 31230761 & 643661 & 515582 & 5086134 & 108122777 \\
\hline Laboratóriumi ellátás & 44190370 & 6432073 & 25814064 & 662443 & 231252 & 6376955 & 83707157 \\
\hline $\mathrm{CT}, \mathrm{MRI}$ & 1269512065 & 165517619 & 802117767 & 39256455 & 5736220 & 45690464 & 2327830590 \\
\hline PET & 345697 & 56843 & 223535 & 6145 & 0 & 0 & 632220 \\
\hline $\begin{array}{l}\text { Aktívfekvőbeteg- } \\
\text { szakellátás }\end{array}$ & 5901485245 & 1010522340 & 4561384485 & 121784363 & 11719945 & 966650705 & 12573547083 \\
\hline $\begin{array}{l}\text { Krónikusfekvőbeteg- } \\
\text { szakellátás }\end{array}$ & 68026200 & 10543170 & 44532840 & 2576310 & 0 & 649110 & 126327630 \\
\hline Tételes elszámolás & 0 & 0 & 0 & 0 & 0 & 0 & 0 \\
\hline $\begin{array}{l}\text { Gyógyszer- } \\
\text { ártámogatás }\end{array}$ & 1192663815 & 117972594 & 700314819 & 30256347 & 161587 & 4185696 & 2045554858 \\
\hline $\begin{array}{l}\text { Gyógyászati segéd- } \\
\text { eszközök ártámogatása }\end{array}$ & 271621555 & 96644273 & 1215463782 & 30903927 & 1183803 & 7814331 & 1623631671 \\
\hline Összesen & 9441443852 & 1504629412 & 7889502070 & 243930501 & 26798628 & 2565226582 & 21671531045 \\
\hline
\end{tabular}

$\mathrm{CT}$ = komputertomográfia; MRI = mágnesesrezonancia-képalkotás; NEAK = Nemzeti Egészségbiztosítási Alapkezelő; PET = pozitronemissziós tomográfia

\section{Megbeszélés}

Tanulmányunkban a vastag- és végbéldaganat kezelésével összefüggő, országos egészségbiztosítási kiadás vizsgálatát tűztük ki célul a 2018-as évi adatok felhasználásával. A vastagbél-, az emlő- és a méhnyakszürés bevezetése kapcsán 2001 körül készültek már egészséggazdaságtani elemzések, melyek a hasonló módszertan miatt összehasonlításra adnak lehetőséget. 2001-ben 9,98 milliárd Ft-ot (38,9 millió EUR) fordítottak a vastag- és végbéldaganat ellátására [30], ami kevesebb mint a fele a 2018-ban kalkulált költségeknek. Ugyancsak 2001 -ben 8,6 milliárd Ft-ot fordítottak az emlőrák kezelésére [31] és 1 milliárd Ft-ot a méhnyakrák kezelésére [32]. 2010-ben az emlőrákos betegek ellátása 12 milliárd Ft-ba került [33].

Európában a daganatellátásra fordított egészségügyi direkt kiadások 1995 és 2018 között 52 milliárd EURról 103 milliárd EUR-ra nőttek (2018-as árfolyamokon). A 98\%-os növekedés hátterében a kezelési költségek emelkedése mellett az újonnan diagnosztizált betegek számának 50\%-os emelkedése is áll. A daganatos betegségek kezelésére fordított direkt egészségügyi kiadások 86\%-kal, 105 EUR-ról 195 EUR-ra nőttek 1995 és 2018 között. A becslések szerint Magyarország a GDP 6,6\%-át (13 992 millió EUR PPP; 1431 EUR $\mathrm{PPP} /$ fó) költötte 2018-ban egészségügyi ellátásra, ennek 7,1\%-át (993 millió EUR PPP; 102 EUR PPP/fö) fordította daganatkezelésre [34].

Inotai és mtsai a kutatásukban több daganattípus költségeit vizsgálták, miszerint 2011-ben a tüdőrák átlagos kezelési költsége volt betegenként a legmagasabb (2544 EUR), míg a második legmagasabb összeget a vastag- és végbéldaganatok ellátására fordították (1920 EUR/beteg). A vastag- és végbéldaganat esetében a C18-C20-as kódok szerinti betegségtípusokat vonták be az elemzésbe [7]. A 2018. évi adatok alapján a C18-C20-as kódok szerinti daganattípusok esetén a fekvőbeteg-ellátás átlagos költsége 2484 EUR volt páciensenként, mely 2011 ben 1392 EUR volt.

A költségek jelentős részét a fekvőbeteg-szakellátásra fordított kiadások teszik ki. A 2000-es évek óta a daganatos betegek fekvóbeteg-szakellátásban eltöltött ápolási napjai csökkenő tendenciát mutatnak, annak a folyamatnak a részeként, hogy az új kezelési módok, orális gyógyszerformák alkalmazása lehetővé teszi az ambuláns ellátást és az otthoni kezelést [34]; de talán ezt a jelenséget befolyásolja az otthoni szakápolás, a palliatív és hospice- 
ellátás emelkedő szerepvállalása is. Adataink szerint a fekvőbeteg-szakellátás a teljes költség 58,0\%-át tette ki, 2001-ben még a 76\%-a volt [26].

A daganatellenes gyógyszerekre fordított összkiadás 2008 és 2018 között megduplázódott Európában, 14,6 milliárd EUR-ról 32,0 milliárd EUR-ra (2018-as árakon és árfolyamokon). A gyógyszerek a közvetlen költségek több mint felét tették ki Bulgáriában (68\%), Magyarországon, Horvátországban és Spanyolországban 2018ban [34]. Adataink alapján a nem direkt onkoterápiás gyógyszerköltség 0,2-12,6\% között változik az egy-egy daganattípushoz kapcsolódó teljes költségen belül (C18: 12,6\%, C19: 7,8\%; C20: 8,9\%; C21: 12,4\%, D010D014: 0,6\%, D12: 0,2\%). A korai vagy benignus daganatok esetében nem is várhatunk el igazán magas gyógyszerköltségeket. A magyarországi gyakorlat és az egészségbiztosítási elszámolás alapján a magas onkoterápiás gyógyszerköltségek döntően a fekvőbeteg-ellátás keretei között jelennek meg, kúraszerű ellátás formájában.

A prevalencia alapján a legtöbb betegségtípus esetében (kivéve a C21-es és a D010-es kód szerintieket) a fekvőbeteg-szakellátás terén magasabb a férfiak aránya, így a költségek magasabb aránya is a férfiakhoz kapcsolódik. Ezekben a korábbi betegségállapotot jelző kategóriákban viszont elképzelhető a nők általában komolyabb egészségtudatossága, korábbi orvoshoz fordulása. Shugarman és mtsai kutatásában a nők átlagos kiadásai 1600 USD-val voltak magasabbak, mint a férfiakéi, ami az otthoni egészségügyi és a hospice-szolgáltatásokra fordított magasabb átlagos kiadásoknak tudható be. A fekvőbeteg-szakellátást igénybe vevő 68-74 éves elhalálozottak körében a fekvőbeteg-kiadások magasabbak voltak a nók esetében, mint a férfiak körében [35]. A jelen kutatásban is a 65-74 éves korosztályhoz kapcsolódik a legmagasabb kiadás. Ennek valószínúsíthető magyarázata az invazív rákok ezen életkori kategóriában előforduló magas száma mellett az, hogy a mai modern szupportív ellátás mellett ebben az életkorban agresszív kombinált onkoterápiás kezelések is kivitelezhetők, melyek gyógyszerköltsége értelemszerúen sokkal magasabb.

A direkt költségek mellett nagy jelentőséggel bírnak az indirekt költségek is. Becslések szerint az informális gondozási költségek összege majdnem akkora lehet, mint a daganatellátásra fordított összes egészségügyi kiadás (2018-ban: 23,2 milliárd EUR). Az informális gondozás a rokonok, barátok által nyújtott gondozásra vonatkozik, például a beteg kórházba kísérése kezelésre, a beteg otthoni ápolása, mely költségeket az egészségbiztosítási rendszer nem téríti meg. Egy másik megközelítés, miszerint a sikertelen kezelés és a korai halál miatt 42,6 milliárd EUR, a táppénzes munkanapok miatt 9,43 milliárd EUR volt a termelékenységveszteség Európában 2018-ban. A vastagbéldaganat gazdasági költségei a harmadik legnagyobb összeget tették ki (13,1 milliárd EUR, 10\%), a tüdőrák és az emlőrák után [34]. Magyarországon a daganatosbetegség-csoport minden évben az első négy között volt a táppénzes napok tekintetében. 2014 és 2016 között az egy esetre jutó táppénzes napok száma a második leginkább elhúzódó, átlagosan 66-70 napot kitevő táppénzes állomány a daganatos betegségekhez tartozott. Jelentős különbség mutatkozik a nemek között, ugyanis az érintettek 62-64\%-a nő volt, és az általuk igénybe vett napok száma 2016-ban 20\%-kal több volt a férfiakénál [36].

\section{Következtetés}

Összegzésként megfogalmazhatjuk, hogy a magyarországi egészségbiztosítási betegségteher elemzésének eredményei azt mutatják, hogy a vastag- és végbéldaganatok éves egészségbiztosítási kiadásai - a jelen különszámban publikált más kórképekhez viszonyítva - igen magasak. Ezen szempont is megerősíti egészség-gazdaságtani oldalról a vastag- és végbéldaganatok okozta társadalmi teher jelentőségét, és megerősíti az ezzel kapcsolatos intervenció, az egészséges életmódra nevelés és a lakossági szûrővizsgálatok indokoltságát.

Anyagi támogatás: A kézirat az „EFOP-3.6.2-16-201700009: Klinikai kutatások tematikus hálózatának kialakítása és nemzetköziesítése" projekt keretében az "Egészségbiztosítási és klinikai real-world adatvagyon hasznosítása” alprojekt támogatásával készült.

Szerzői munkamegosztás: A vizsgálat tervezése és lefolytatása: B. I., En. D., K. Zs. Az adatok gyưjtése és ellenőrzése: K. Zs., B. I., En. D., El. D., K. L. F. Adatfeldolgozás és adatelemzés: K. Zs., El. D., Cs. T., M.-V. R. Statisztikai elemzések: El. D., K. Zs., B. I. Az eredmények értékelése: K. Zs., En. D., El. D., B. I., M. L. Irodalomkutatás: K. Zs., El. D., M.-V. R. A kézirat megszövegezése: K. Zs., En. D., El. D, Cs. T., K. L. F., B. I., M. L., M.-V. R. A cikk végleges változatát valamennyi szerző elolvasta és jóváhagyta.

Érdekeltségek: A szerzőknek nincsenek érdekeltségeik.

\section{Köszönetnyilvánítás}

A dolgozat szerzői köszönetet mondanak az „EFOP-3.6.2-16-2017 00009: Klinikai kutatások tematikus hálózatának kialakítása és nemzetköziesítése" projekt keretében nyújtott támogatásért (szakmai vezető: prof. dr. Kovács L. Gábor, a Magyar Tudományos Akadémia rendes tagja).

\section{Irodalom}

[1] Ferlay J, Ervik M, Lam F, et al. Global cancer observatory: cancer today. International Agency for Research on Cancer, Lyon, 2018. Available from: https://gco.iarc.fr/today [accessed: September 10, 2020].

[2] National Cancer Registry. [Nemzeti Rákregiszter.] Országos Onkológiai Intézet, Budapest. Available from: https://onkol. hu/nemzeti-rakregiszter/ [accessed: July 20, 2020]. 
[3] Hungarian Central Statistical Office. Yearbook of health statistics - 2018. [Egészségügyi statisztikai évkönyv - 2018.] Központi Statisztikai Hivatal, Budapest, 2019. [Hungarian]

[4] Gatta G, Trama A, Capocaccia R. Variations in cancer survival and patterns of care across Europe: roles of wealth and healthcare organization. J Natl Cancer Inst Monogr. 2013; 46: 79-87.

[5] Allemani C, Rachet B, Weir HK, et al. Colorectal cancer survival in the USA and Europe: a CONCORD high-resolution study. BMJ Open 2013; 3: e003055. [Erratum: BMJ Open 2013; 3: e003055corrl.]

[6] Tusnády G, Gaudi I, Rejtő L, et al. Survival chances of Hungarian cancer patients in the National Cancer Registry. [A magyar daganatos betegek túlélési esélye a Nemzeti Rákregiszter adatai alapján.] Magy Onkol. 2008; 52: 339-349. [Hungarian]

[7] Inotai A, Abonyi-Tóth Zs, Rokszin Gy, et al. Prognosis, cost, and occurrence of colorectal, lung, breast, and prostate cancer in Hungary. Value Health Reg Issues 2015; 7: 1-8.

[8] Organisation for Economic Co-operation and Development (OECD). Available from: https://stats.oecd.org/\# [accessed: January 16, 2021].

[9] State of Health in the EU. Hungary: Country Health profile 2017. [State of health in the EU. Magyarország: Egészségügyi országprofil 2017.] OECD Publishing, Paris/European Observatory on Health Systems and Policies, Brussels. Available from: http://dx.doi.org/10.1787/ 9789264285231-hu [accessed: January 16, 2021]. [Hungarian]

[10] Boncz I, Sebestyén A, Döbrôssy L, et al. The role of immunochemical testing for colorectal cancer. Lancet Oncol. 2006; 7: 363-364.

[11] Kívés Zs, Kovács A, Budai A, et al. Quality and performance indicators of colorectal cancer screening pilot programme in Csongrád county. [A Csongrád megyei vastagbélszúrési pilot program minőségi indikátorai és teljesítménymutatói.] Magy Onkol. 2019; 63: 125-132. [Hungarian]

[12] Kívés Zs, Juhász K, Csákvári T, et al. Cancer screening policy in Hungary. Int J Cancer 2018; 143: 1003-1004.

[13] Yabroff KR, Borowski L, Lipscomb J. Economic studies in colorectal cancer: challenges in measuring and comparing costs. J Natl Cancer Inst Monogr. 2013; 2013: 62-78.

[14] Zadlo J. Cost-effectiveness of new and emerging treatment options for the treatment of metastatic colorectal cancer. Am J Manag Care 2018; 24(7 Suppl): S118-S124.

[15] Boncz I, Sebestyén A. A comparative analysis of the costs of treating breast, cervical, and colorectal tumors. [Az emlö, méhnyak és colorectalis daganatok kezelési költségeinek összehasonlító elemzése.] Inform Menedzsment Eü. 2005; 4(10): 16-19. [Hungarian]

[16] Boncz I, Sebestyén A, Pintér I, et al. Age-group specific gap between treatment cost of and mortality due to breast and colorec tal cancer. J Clin Oncol. 2007; 25: 4501-4502.

[17] Boncz I, Brodszky V, Péntek M, et al. The disease burden of colorectal cancer in Hungary. Eur J Health Econ. 2010; 10(Suppl 1): S35-S40.

[18] Boncz I, Zemplényi A, Horváthné Kívés Z, et al. Health insurance treatment cost of colorectal cancer in Hungary. Value Health 2016; 19: A610.

[19] Boncz I, Németh M, Orosz E, et al. FIT performance in earlystage colorectal cancer - letter. Cancer Epidemiol Biomarkers Prev. 2011; 20: 1562.

[20] Ran T, Cheng CY, Misselwitz B, et al. Cost-effectiveness of colorectal cancer screening strategies. A systematic review. Clin Gastroent Hepatol. 2019; 17: 1969-1981.el5.
[21] Siegel RL, Miller KD, Sauer GA, et al. Colorectal cancer statis tics, 2020. CA Cancer J Clin. 2020; 70: 145-163.

[22] National Public Health Center. Complex public health screen ings. [Komplex népegészségügyi szűrések.] Nemzeti Népegészségügyi Központ, Budapest, April 6, 2018, and October 15, 2020. Available from: https://www.nnk.gov.hu/index.php/ nnk-projektek/komplex-nepegeszsegugyi-szuresek [accessed: January 16, 2021].

[23] Boncz I, Evetovits T, Dózsa Cs, et al. The Hungarian Care Managing Organization Pilot Program. Value Health Reg Issues $2015 ; 7: 27-33$.

[24] Varga V, Boncz I, Sebestyén A, et al. Utilization indicators of balneotherapy in Hungary. [A gyógyfürdőellátások igénybevételi mutatói Magyarországon.] Orv Hetil. 2019; 160(Suppl 1): 2228. [Hungarian]

[25] Boncz I, Vajda R, Ágoston I, et al. Changes in the health status of the population of Central and Eastern European countries between 1990 and 2010. Eur J Health Econ. 2014; 15(Suppl 1): S137-S141.

[26] Endrei D, Molics B, Ágoston I. Multicriteria decision analysis in the reimbursement of new medical technologies: real-world experiences from Hungary. Value Health 2014; 17: 487-489.

[27] Boncz I, Sebestyén A. Financial deficits in the health services of the UK and Hungary. Lancet 2006; 368: 917-918.

[28] Eisingerné Balassa B, Csákvári T, Ágoston I. Health insurance pharmaceutical expenditures in Hungary. [Az egészségbiztositási gyógyszerkiadások alakulása Magyarországon.] Orv Hetil. 2019; 160(Suppl 1): 49-54. [Hungarian]

[29] Boncz I, Nagy J, Sebestyén A, et al. Financing of health care services in Hungary. Eur J Health Econ. 2004; 5: 252-258.

[30] Boncz I, Sebestyén A, Dózsa Cs, et al. Health economics analysis of colorectal screenings. [A colorectalis szürések egészség-gazdaságtani elemzése.] Magy Onkol. 2004; 48: 111-115. [Hungarian]

[31] Boncz I, Sebestyén A, Gulácsi L, et al. Health economics analysis of breast cancer screening. [Az emlőrákszürések egészség-gazdaságtani elemzése.] Magy Onkol. 2003; 47: 149-154. [Hungarian]

[32] Boncz I, Sebestyén A, Pál M, et al. Health economics analysis of cervical cancer screening. [A méhnyakrákszúrések egészség-gazdaságtani elemzése.] Orv Hetil. 2003; 144: 713-717. [Hungarian]

[33] Boncz I, Vajda R, Csákvári T, et al. Assessment of health insurance costs of mammography breast screening. [A mammográfiás emlőszûrési programhoz kapcsolódó egészségbiztosítási kiadások meghatározása.] Egészség-Akad. 2015; 6: 12-21. [Hungarian]

[34] Hofmarcher T, Brådvik G, Svedman C, et al. Comparator report on cancer in Europe 2019 - disease burden, costs and access to medicines. IHE Report 2019: 7. Swedish Institute for Health Economics, Lund.

[35] Shugarman LR, Bird CE, Schuster CR, et al. Age and gender differences in medicare expenditures at the end of life for colorectal cancer decedents. J Womens Health 2007; 16: 214-227.

[36] Hungarian Central Statistical Office. Sick pay, 2014-2016. [Táppénz, 2014-2016.] Központi Statisztikai Hivatal, Budapest, 2017. Available from: https://www.ksh.hu/docs/hun/xftp/ idoszaki/pdf/tappenzl6.pdf [accessed: January 16, 2021]. [Hungarian]

(Kívés Zsuzsanna, Pécs, Vörösmarty u. 3., 7621 e-mail: zsuzsa.kives@etk.pte.hu)

A cikk a Creative Commons Attribution 4.0 International License (https://creativecommons.org/licenses/by/4.0/) feltételei szerint publikált Open Access közlemény, melynek szellemében a cikk bármilyen médiumban szabadon felhasználható, megosztható és újraközölhető, feltéve, hogy az eredeti szerző és a közlés helye, illetve a CC License linkje és az esetlegesen végrehajtott módositások feltüntetésre kerülnek. (SID_1) 